\title{
Islamic Marketing Ethics and Its Impact on Customer Satisfaction in the Islamic Banking Industry
}

\author{
Abul Hassan, Abdelkader Chachi" and Salma Abdul Latiff** \\ Research Fellow at the Markfield Institute of Higher Education, Leicestershire, UK \\ * Researcher, Islamic Economics Research Centre, King Abdulaziz University, \\ Jeddah, Saudi Arabia. ** Director of Centre for Islamic Banking, Finance and \\ Management, University Brunei Darussalam
}

\begin{abstract}
Islamic marketing ethics combines the principle of value maximisation with the principles of equity and justice for the welfare of the society. Adherence to the Islamic ethics in the Islamic banking industry can help elevate the standards of both behaviour and living of bankers and customers alike. In a rapidly changing marketing environment the need to be customer-focused has never been as important as it is today. At present where customers are becoming more demanding and increasingly mobile between competing financial providers, being customer-focussed is not enough. Islamic banks and more specifically their customer-contact employees (customer relation advisers or officers) need to be perceived by their customers as being Islamic.

This study represents an initial step in analysing the role of Islamic ethical sales behaviour as it may be perceived by the customers of Islamic Banks.
\end{abstract}

\section{Introduction}

The basic difference between Islamic and conventional banks lies in the fact that the former operate on an equity-participation system in which a predetermined rate of return is not guaranteed, whereas the latter's operations are based on both equity and debt systems that are mainly driven by interest (riba). This essential difference, resulting from the implementation of the Islamic Shari'ah principles, provides the incentive for Islamic bankers to search for different products/services to offer. Although the idea of Islamic banking is relatively new, being no more 
than two decades old, it has nevertheless attracted the attention of many investors around the world. From a strategic point of view, this newness is both advantageous and disadvantageous at the same time. Thus, on the positive side, being a nascent idea, Islamic banking has the potential for attracting new customers and consequently, enhancing a bank's market share. This phenomenon may explain the increase in the branches of some Islamic banks (e.g. the Dubai Islamic Bank, UAE; Islamic Bank Bangladesh Limited; Bank Islam Malaysia Berhad; Bank Shariya Mandiri, Indonesia, etc.,) which have established many branches in their respective countries.

On the negative side, however, a high potential for expansion motivates new entrants to the industry and as a result, provokes more competition. Indeed, many conventional multinational and commercial banks - e.g., City Bank, Standard Chartered Bank, HSBC Barclays, Bank, etc., - have already opened "Islamic windows" through which Islamic business activities are conducted. There is a similar situation elsewhere in Bangladesh, Malaysia, the Middle East and the lesserdeveloped countries. As a result of these developments, an Islamic bank can be expected to face competition not only from the Islamic windows of conventional commercial banks, but also from other Islamic banks. Hence, the marketing strategy of an Islamic bank must be concerned with its ability to gain a competitive advantage and establish a strong competitive position.

The Islamic marketing principles combine a value-maximization concept with the principle of 'justice' for the wider welfare of the society. These principles offer a means to create value and elevate the standard of living of people in general through commercial pursuits. The Islamic ethical guidelines ensure respect for, and the individual freedom of, both bankers and customers. Islamic ethics dictate that under no circumstances should marketers exploit their customers or in any way involve themselves in dishonesty, fraud or deceit. Any unethical marketing practice does an injustice, which, by definition, negates the concepts of brotherhood and equality of humanity that form the core of the Islamic vision (Saeed, Ahmad and Mukhtar, 2001). Thus, adopting the Islamic marketing ethics ensures that the seeds of harmony are planted and a proper order in society is provided, thereby enhancing the dignity of, and upholding the rights of human beings. 
In banking institutions, the Customer Relation Advisor (CRA) is the most visible representative for the company (Enis 1980; Crosby et al., 1990). In Crosby et al.,'s (1990:68) words: “frequently the service salesperson (customer relation advisor) is the primary - if not sole contact point for the customer both before and after the purchase". Consequently, the firm's sales force is critical to its service delivery process (Shepherd 1999). At the same time, sales-people (customer relation advisors) are exposed to greater ethical pressures than individuals in many other jobs. They work in relatively unsupervised settings, they are primarily responsible for generating the bank's revenues, which at times can be very stressful; and they are often evaluated on the basis of short-term objectives (Wotruba 1990).

It can happen that a customer relation advisor (CRA) behaves unethically when interacting with different stakeholders such as customers, competitors or his employer. However, in the hierarchy of stakeholder importance, it appears that the CRAs regard ethical transgressions against customers as being more serious than any controversial actions taken against competitors or employers (Chonko and Burnett 1983; Chonko and Hunt 1985). When competition intensifies and when banks start to offer more or less similar products and services, it is the customer's perception of satisfactory service provided by the customer relation advisor (CRA) that can influence the performance of an Islamic bank and determine its competitiveness and success.

The need to be customer-focused in the rapidly changing marketing environment has never been more important for Islamic banks and financial services institutions than it is nowadays. However, under the present circumstances, where customers are becoming more demanding and increasingly mobile between competing financial providers, being customer-oriented is not enough. Islamic banks and more specifically their contact employees (customer relation advisors) need to be perceived by their customers as ethically Islamic.

The issue of marketing ethics in Islamic banking perspective is an under researched area. There is a lack of published literature from the Islamic perspective on marketing ethics applicable to banking system. This study is designed to fill in the gap and its main objective is to identify the salient features of Islamic marketing ethics and to analyse the possible role of Islamic ethical sales behaviour as may be perceived by the customers of Islamic Banking. 
This study is divided into four sections. Section one is an introduction. Section Two discusses the five Ps of the marketing-mix within the context of marketing as determined by Islamic ethical values. Section Three analyses the Islamic ethical sales behaviour on customer satisfaction in developing and maintaining relationships with customers of Islamic banking. Section Four presents the conclusions.

\section{The Five Ps of the Marketing-Mix from the Islamic Perspective}

In defining Islamic Marketing ethics, Saeed, Ahmad and Mukhtar, (2001) state that Islamic marketing ethics based on the principles of justice and equity in Islam differs from secular ethics in many ways. They discussed the three characteristics of market ethics from the Islamic perspective. Firstly, Islamic ethics are based on Qur'anic commandments and leave no room for ambiguous interpretation by marketing executives to suit their individual whims and desires. Secondly, the main difference is their transcendental aspect of absoluteness and non-malleable nature. Thirdly, the Islamic approach emphasizes value-maximization in view of the greater good of the society rather than the selfish pursuit of profit maximisation. Such properties grant Islamic ethics a tremendous capacity to penetrate human conscience and are capable of influencing the behaviour of marketing executives from within.

Banking or commercial activity from an Islamic perspective is governed by two principles: (i) submission to the moral order of God and (ii) empathy and mercy to God's creations which implies refraining from doing harm to others and thus preventing the spread of unethical practices (Niazi, 1996). In this section, an attempt is made to analyse the five Ps of marketing ethics within the context of 'marketing' as determined by Islamic ethics. The five Ps are: product, price, promotion, place and people.

\subsection{Product/Production Process}

The development of Islamic banking products should be visualized quite differently as compared to Western thinking. The Islamic perspective incorporates moral and transcendental elements within the production decision-making process in product development and is guided by the principles of Islamic business ethics (al-Misri, 1991). These principles dictate, as Ibn al-Ukhuwwah (1938) remarked, that firstly, the product should be lawful and not to cause dullness of mind in 
any form. Secondly, the product must be asset backed. Thirdly, the product must be deliverable since the sale of a product is not valid if it cannot be delivered. Fourthly, there is a need of identification of extra cost-added features that might materially change the product or impact on the buyer's purchase decisions. Fifthly, all parties intend to discharge their obligations, financial and otherwise, in good faith; and should be based on principle of the justice, fairness and equity.

Under the Islamic approach, the production process has to be guided by the criteria of the value and the impact of the product upon the whole society. This is due to the highest importance given to the actualization of the optimum welfare of a human being and society (al-Faruqi, 1992). The primary objective of the development of suitable banking product is to deliver, elevate and satisfy basic human needs. Miller (1996) suggest that the main thrust behind unethical decision-making on the part of business persons to produce sub-optimal products is usually some form of costconscious strategy. The Islamic perspective, on the other hand, encourages a societal and welfare approach rather than decisions based on the profit maximization.

\subsection{Product Pricing}

Pricing policies are, in the main, formulated to exploit and manipulate human psychology as witnessed by common practice whereby the recommended retail price printed on a product is often substantially higher than what retailers actually charge. The aim of such pricing policies is to give customers a false impression that they are in fact getting a bargain (Shaw, 1996). This type of practice is banned under Islamic law. Islam prohibits getting something too easily without hard labour, or receiving a profit without working for it (Shaw, 1996). Furthermore, it is not allowed to change a price without altering the quality or quantity of the product because this is cheating the easy-going customer for illicit gain (Ibn Taymiyah, 1982).

Islam also prohibits false propaganda or publicity on the part of marketers regarding the position of demand and supply through the media. It should be pointed out that Islam does not prohibit price controls and manipulations to meet the needs of the market. It means that the Islamic ethics allows some time in which to charge higher prices as a result of natural scarcity of supply of a given commodity or setting price ceilings to curb opportunistic tendencies among merchants. Islamically, 
self-operating mechanism of price adjustments and healthy competition are to be encouraged (al-Qur'an, 83:26). However, the essential conditions for the successful operation of such a mechanism dictate that there should be no corner market, no hoarding, no unjustified price manipulation, and no restriction on trade (Niazi, 1996). Once the second Caliph Umar Ibn al-Khattab passed by Hatib ibn Abi Balta'ah and found him selling raisins at a much lower price with the intention of putting his competitors to loss. Caliph Umar Ibn al-Khattab told him: "Either enhance your rate or get away from our market" (Malik, 1989).

The hoarding of any product is strictly prohibited in Islam. But the system offers flexibility if competing marketers sell at one price amounts to coercion and distortion of the free market or if it means very high product prices. Under these circumstances, officials of the Islamic government can bring together market leaders representing a particular region or a particular commodity, in the presence of others. The purpose is to reach a consensus on price level that would not be unjust to the consumer and at the same time reap reasonable profits to the marketers. The key impetus to intervene on such an ad-hoc basis is to prevent "black-marketing" and "concealment of essential foodstuffs".

Ibn al-Ukhuwwah (1938) discusses many types of contemporary "ethical lapses" in pricing. Examples given by him include when real owners of the products pretend that they are not the owners in order to hike up the price by making consumers believe that an even higher price would be charged by the real traders, or when there are collusive agreements. He, therefore, emphasises the role of a public welfare official to ensure that prices remain fair and just by curbing any ethical lapses in price setting. He observes that "the public welfare official must see that a broker receives his commission only from the seller and must not cause the price to be abated in collusion with the buyer' (Ibn alUkhuwwah, 1938:4). All unethical lapses in pricing are tantamount to 'injustice' and are sinful. Hence, all profits earned through such unjustified prices are not only unethical, but they infringe upon the unique status of man/woman and his/her role and responsibilities as viewed under the Islamic framework. The Prophet Muhammad (Peace be upon him) remarked, "Do not raise prices in competition" (al-Nawawi, $2: 270$ ). In order to eliminate this type of 'injustice', the marketer and customer must acknowledge that they have higher moral responsibilities on earth rather than be preoccupied with profit maximization alone. 


\subsection{Product Promotion Rules}

There is no room in Islam to justify any cover up of deceptive promotional behaviour. Al-Qur'an condemns all forms and shapes of false assertion, unfounded accusation, concoction and false testimony (alQur'an, 43:19). In terms of Islamic marketing ethics, it is unethical for the salesman or customer relation advisor (CRA) to over-praise his products and attribute to them qualities which they do not possess (Ibn al-Ukhuwwah, 1938). Furthermore, giving a false impression of any kind to promote or sell a product is strictly prohibited within the Islamic ethical framework of international marketing practices. Therefore, in the area of product promotions, Islamic marketing ethics will follow the following rules:

(i) avoidance of false and misleading advertising;

(ii) rejection of high pressure manipulations, or misleading sales tactics;

(iii) avoidance of sales promotions that use deception or manipulation.

According to Islamic ethics, a seller is a person who feels accountable to God. He should be honest and fair in his marketing activities. Only true documents which reveal accurate specifications in terms of quality, contents, etc. will exchange hands. To practice otherwise constitutes disgraceful, dishonourable and shameful gain through pandering, deceit, treachery, theft or injustice (Ibn-Miskawayh, 1968). According to Islamic principles, marketers are required to "disclose all faults in their goods, whether obvious or hidden; to do otherwise is to act... fraudulently" (Ibn al-Ukhuwwah, 1938:42). It is obligatory for the seller to reveal all known defects which cannot be seen "on the surface" and cannot be found out by the "cursory glance" to the purchaser (Niazi, 1996:196). In addition, it is dictated that - "A sale without any stipulation makes it necessary that the thing sold should be free from defect" (Tyser et al., 1967). Marketing disclosure is manifested either by assurance which will be given by word of mouth or in writing, or in some cases silence will mean assurance (Niazi, 1996:197). The Prophet Muhammad (Peace be upon him) expressly condemned all manipulative promotional behaviour stating that, "One who cheats us is not one of us" (al-Nawawi 2: 770). 
In Islamic ethics, promotional techniques must not use sexual appeal, emotional appeal, fear appeal, false testimonies and pseudo research appeal, or contribute to the dullness of the mind or encourage extravagance. Within the Islamic framework, these methods are unethical since they are utilized purely to exploit the basic instinct of consumers worldwide with a view to gain profits and greater market share. Furthermore, Islamic ethics strictly prohibits stereotyping of women in advertising, and excessive use of fantasy. The use of suggestive language and behaviour, and the use of women as objects to lure and attract customers are also not allowed.

\subsection{Place: Distribution Channels}

The ethical dimensions of decision-making pertaining to distribution are of great significance in the area of marketing. Physical distribution can be viewed as an integrated collection of information, people, equipment, and organization. In respect of distribution of product, therefore, Islamic financial institutions will follow the following principles:

(i) Not manipulating the availability of a product for purpose of exploitation;

(ii) Not using coercion in the marketing channel;

(iii) Not exerting undue influence over the re-sellers choice to handle a product.

It is not surprising to note that decisions made on the profit maximization principle are not necessarily the most appropriate for a society's welfare. Other cases of unethical practices in distribution include the usage of packaging designs without adequate security and protection for the product, inappropriate packaging, and dangerous and toxic products transported through public highways. From an Islamic perspective, such treatment of customers is unforgivable and equates to unjust marketing practices.

According to Islamic principles, distribution channels are not supposed to create a burden for the final customer, in terms of higher prices and delays. Ibn al-Ukhuwwah (1938), for example, identifies, in particular, ethical lapses in distribution channels as those which cause unnecessary delays in their delivery, compelling customers to return repeatedly and thus causing them unnecessary inconveniences (Ibn alUkhuwwah, 1938:44, 48). Islam does not prohibit agency representation 
as a link in the market to facilitate the movement and acquisition functions. Within the Islamic ethical framework, however, the main aim of distribution channels should be to create value and uplift the standard of living by providing ethically satisfactory services.

\subsection{People}

Islam emphasises the importance of "free" and "independent judgment" on the part of the customer. The ability to think rationally while making any decision relating to global marketing activities is a prerequisite in Islamic law (Ahmad, 1995). The society at large should not be deprived of honest, free from coercion marketing information. A customer's right to acquire such information is his right and is indicative of the status given to him by Islam, as well as of the ingrained rights of his wealth which he spends in purchasing products and services. It is the responsibility of the marketers not to resort to any form of coercion and they must, under all circumstances, have a regard for the intellectual integrity and a higher degree of consciousness of the consumers to ensure that the hard earned money of customers is not wasted. Coercion or 'ikrah' (Al-Qur'an 23:7), as defined by Tyser et al., (1967:149-150), is to compel a person to do a thing without his consent. It follows therefore, that whenever some coercive force is applied for the purposes of concluding a global marketing deal, the fundamental and vital condition of mutual consent remains unfulfilled and the resultant transaction is unethical and unlawful. The Prophet Muhammad (Peace be upon him) prohibited a transaction concluded under constraints or bay' al-Mudtarr (Ahmad, 1995:126). According to Islamic principles, sexual appeal, emotional appeal, fear appeal, subliminal advertising and pseudo scientific claims all have elements of coercion which cause them to be categorized as unethical as a means of marketing. An ethically sound marketing-mix, therefore, dictates that customers' decision-making freedom must be protected from all elements of coercion.

\section{The impact of Islamic Ethical Sales Behaviour on Customer Satisfaction within Islamic Banking Services Industry}

This section focuses on customer relation advisors' Islamic ethical behaviour which takes place during the interaction between him and a customer of an Islamic bank. Islamic ethics requires an individual to behave according to the rules of Islamic moral philosophy. Islamic ethics 
is a standard for judging the rightness not of an action per se, but of the action of one person relative to another, i.e. Islamic ethics is a basis for judgment in personal as well as collective interaction. Based on previous research (Dubinsky et al., 1991; Futrell, 2002) in the context of this study, unethical sales behaviour is defined as a CRA's short-run conduct that enables him to gain at the expense of the customer. Examples of such activities include: Lying or exaggerating about the benefits of a product/service; selling products/services that people do not need; lying about availability; lying about the competition; giving answers when the answer is not really known; and implementing manipulative influence tactics or high-pressure selling techniques (Wray et al., 1994; Howe et al., 1994; Tansey et al., 1994; Cooper and Frank 2002).

A contingency restrictive model of Islamic ethical sales behaviour on customer satisfaction is designed in Fig. 1. Islamic ethical sales behaviour, as perceived by the customer, is proposed to directly influence customer satisfaction, both with the core service and the Islamic bank, trust and loyalty to the Islamic bank (H1-H4). As for the indirect effects, it is suggested that satisfaction with the core service influences satisfaction with the Islamic bank (H5). These two variables, in turn, lead to loyalty (H6 and H7). Finally, satisfaction with the Islamic bank leads to trust (H8), and trust is proposed to increase customer loyalty (H9).

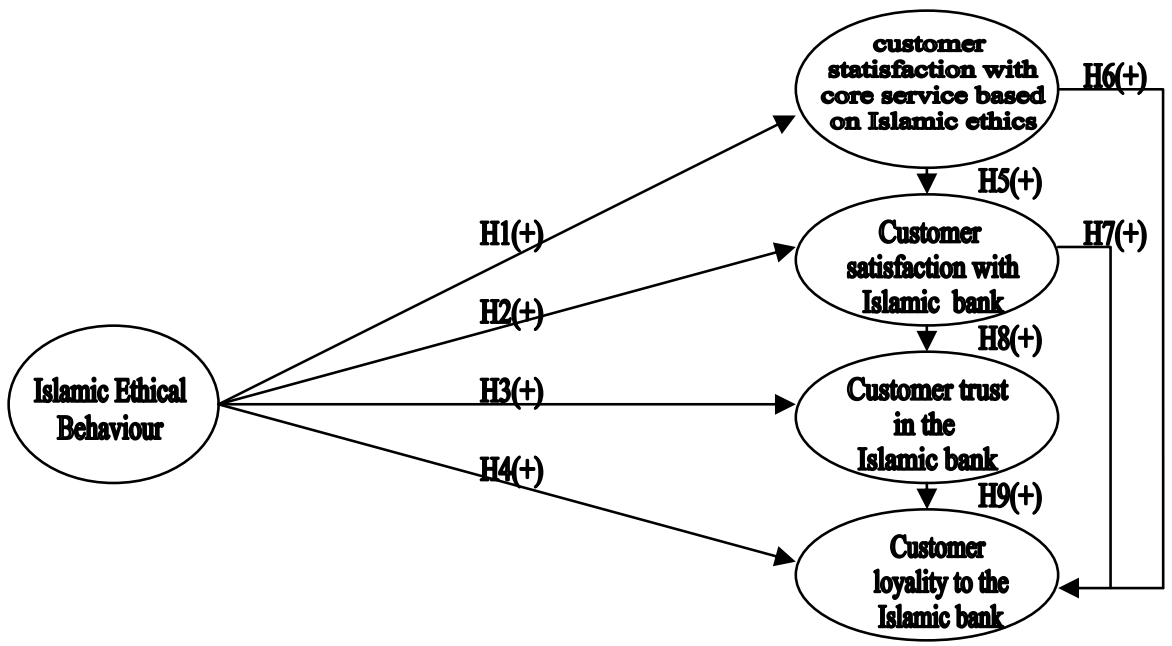

Fig. 1. Consequences of Ethical Sales Behaviour on the Customer. 


\subsection{Possible Direct Effects on Customer Satisfaction, Trust and Loyalty to Islamic Banks}

\subsubsection{Customer Satisfaction}

There are several distinct and separate "objects" about which a consumer will make satisfaction judgements (Singh, 1991). This research focuses on customer satisfaction with the Islamic bank and its core services e.g. Islamic mortgages, pensions, Islamic investment funds, Islamic insurance and credit cards to be offered by the customer relation advisor (CRA) to the customer.

Frontline service employees, such as customer relation advisors, "are the organization in the customer's eyes" (Metawa and al-Mossawi, 1998:300). In many cases, the contact employee is the service - there is nothing else (Hegazy, 1995; Zeithaml and Bitner 2000). Even if the contact employee does not perform the service entirely, he may still personify the bank in the customer's eyes. Each of these customer contacts has the potential of positively or negatively impacting customer's satisfaction with the service as well as the company (Jamal and Naser, 2003). More specifically, the services literature has widely recognised the importance of contact employees' behaviour for customer satisfaction and loyalty (Naser, Jamal and al-Khatib, 1999; Farrell et al., 2001; Ganesh et al., 2000). For example, Solomon et al., (1985:100) pointed out that "customer satisfaction and repeat patronage may be determined solely by the quality of the personal encounter".

According to the expectancy disconfirmation paradigm (Oliver and De Sarbo 1988; Tse and Wilton 1988), consumers make a comparison between service expectations and performance that will result in either confirmation or disconfirmation. Customers' expectations are confirmed when product or service performance exactly meet expectations. Disconfirmation will be the result of a discrepancy between expectations and performance. Positive disconfirmation occurs when product/service performance exceeds prior expectations, and negative disconfirmation occurs when expectations exceed performance. Confirmation and positive disconfirmation will be likely to result in satisfaction, whereas negative disconfirmation leads to dissatisfaction.

Customer expectations regarding the core service are highly dependent on the CRA's presentation in the service encounter (Jamal and Naser, 2003). If the CRA behaves according to Islamic ethics, he is more 
likely to provide realistic expectations about the core service, and is less likely to push the customer into buying a service that the customer does not need. Consequently, these actions may result in confirmation or even positive disconfirmation between expectations and service performance, thus resulting in customer satisfaction with the core service. Some preliminary evidence for such a proposition can be found in the study by Kennedy et al., (2001), where customer satisfaction, in this case with an automobile, was positively related to low-pressure selling tactics.

\subsubsection{Customer Satisfaction with the Core Service}

Results from the study of Naser, et al., (1999) indicate that customer satisfaction with the customer relation advisor (CRA) increased when the customer felt the advisor had been fair in the transaction - something which is associated with Islamic ethical sales behaviour. Later, results from the exploratory study of Jamal and Naser (2003), show that the perceived ethical standard of the CRA had a positive impact on customer satisfaction with the CRA. In some service settings, discriminate validity between satisfaction with the CRA and the organisation should not be necessarily expected (Goff et al., 1997). Derived from these findings, and taking into account that in a service context the CRA and the selling Islamic banks are often indistinguishable in the mind of the customer (Haron, Ahmad and Planisek, 1994), it can be expected that there is a positive association between Islamic ethical sales behaviour and customer satisfaction with the Islamic bank.

\subsubsection{Customer Trust in the Islamic Bank}

Customer trust relates to a belief on the part of the customer that obligations will be fulfilled. In other words, the customer believes and feels that the seller of an Islamic bank product can be relied upon to behave in such a manner that the long-term interest of the customer will be served. Trust in the company is defined as "customer confidence in the quality and reliability of the services offered by the organization" (Garbarino and Johnson 1999:73). This conceptualisation of trust corresponds to the concept of post-trust that derived from the principles of mu'amalat based on Islamic ethics. Service employees (such as CRAs) with whom the customer interacts, confirm and build trust in the organization or detract from its reputation and ultimately destroy trust. Findings from Naser and Mountinho (1997) suggest that Islamic ethical sales practices, as perceived by financial services customers, increased 
customer trust in the CRA. Likewise, different exploratory studies in the conventional field have shown that customer trust in the salesperson can be earned by the honest actions of sales representatives (Swan et al., 1985; Swan et al., 1988; Beatty et al., 1996), as well as low-pressure selling techniques (Strutton et al., 1996; Kennedy et al., 2001).

It can be expected that there is a positive association between Islamic ethical sales behaviour and customer trust in the Islamic bank. This can be explained by taking into account the important role of salespeople (CRA) in the service setting. That is, salespeople (CRAs), as frontline service employees, "are the organisation in the customer's eyes" (Zeithaml and Bitner; 2000, p.287). Consequently, if the behaviour of CRAs is perceived as Islamic, the bank is also likely to be perceived as Islamic, because customer perceptions of contact employees will affect their perceptions of the bank.

\subsubsection{Customer Loyalty to the Islamic Bank}

An important consideration in a service Bank's customer base is the degree to which its customers are loyal (Ganesh et al., 2000). Based on the principles of marketing ethics from an Islamic perspective, customer loyalty to the Islamic bank is conceptualized as a combination of a customer's intention to maintain an ongoing relationship with the Islamic bank, and his willingness to recommend the bank to other consumers (Erol and El-Bdour, 1989; Haron, Ahmad, and Planisek, 1994; Naser and Mountinho, 1997; Jamal and Naser, 2003). Customers' perceptions of face-to-face interaction with the service employees have traditionally been considered one of the most important determinants for loyalty (Naser, et al., 1999).

Islamic ethical sales behaviour is likely to play a major role in developing customer loyalty. From a theoretical perspective Metawa and al-Mossawi (1998) note that unethical sales behaviour is a short-run, expedient perspective devoid of any sense of social responsibility. Likewise, Gundlach and Murphy (1993) argue that following ethical principles allows sellers to foster long-term relationships with buyers. Building on equity theory, Islamic ethical sales behaviour can be considered to be an investment in the equity formulation. If customers feel they are being treated unfairly by the CRA (because of unethical behaviour), perceptions of inequity will emerge which in turn may translate into a desire of the customer to leave the relationship with the 
Islamic bank as represented by that customer relation advisor (CRA). As for the empirical evidence, Trawick et al., (1991) showed that a CRA's behaviour, that is perceived as unethical by the industrial buyer, had a negative impact on intentions to choose the firm represented by that CRA. Furthermore, Whalen et al., (1991) found evidence for a negative relationship between a consumer's perception of a seller's unethical behaviour and purchase intention. Therefore, we can say that the greater the CRA's Islamic ethical behaviour as perceived by the customer, the greater the customer loyalty to the Islamic bank.

\subsubsection{Customer Satisfaction with the Islamic Bank}

Research in services marketing has widely shown that customer satisfaction leads to customer loyalty (Crosby and Stephens 1987; Cronin and Taylor 1992; Taylor and Baker 1994; Dabholkar 2000; Liljander and Mattson 2002). For instance, Crosby and Stephens (1987) find that whether customers had replaced their insurance policies or allowed them to lapse depended on their prior satisfaction with the whole life coverage. Similarly, in their studies, Gerrad and Cunningham (1997); Metawa and al-Mossawi, (1998); Naser, Jamal and al-Khatib (1999) in a sample of Islamic banking found that core-service satisfaction was positively associated with repurchase intentions. Findings from Naser, Jamal and alKhatib (1999), with a sample of Jordan Islamic bank customers, indicate that customer satisfaction with the bank had a significant and positive effect on bank loyalty. Results from Jamal and Naser (2003), obtained with a sample of customers from different service industries, provide evidence of the positive influence of customer satisfaction both with the Islamic bank as service provider and the core service on customer intention to use the facility's services again, and recommend the service Islamic bank to a friend.

With respect to the relationship between satisfaction with the Islamic bank and trust in the bank, the latter has been viewed from a global perspective as an overall impression of the Islamic bank. There is a longterm orientation in this variable, since trust is also conceptualized as "a cumulative process that develops over the course of repeated, successful interactions" (Nicholson et al., 2001; p.4). Satisfying encounters are hypothesized to reinforce customers' trust in the Islamic bank (Haron, Ahmad and Planisek, 1994). A highly satisfying experience with the Islamic bank may not only reassure the customer that his trust in the service provider is well placed, but also enhance it (Metawa and al- 
Mossawi, 1998). Empirical research in marketing channels (Ganesan 1994; Selnes, 1998), and in the consumer behaviour literature (Garbarino and Johnson, 1999) supports this contention.

Due to the unique characteristics of the Islamic banking system, a customer will get natural satisfaction from most aspects of an Islamic bank's products and services. Islamic banks thus, have competitive advantage in terms of enjoying customer confidence. For example, in general, satisfied customers are likely to engage in repeat purchase and reflect strong loyalty towards the Islamic bank. As argued by East (1997) and Richens (1983), satisfied customers like these are likely to engage in positive word of mouth and try line extensions. Since satisfaction is an important component of the total package of value required by customers, Islamic banks can use a segment of satisfied customers in its promotional materials to attract new customers. An Islamic bank can also use images of its caring employees. Employees are a significant part of the service delivery process and play a significant role in companycustomer interaction. Furthermore, an Islamic bank can promote its products using physical evidence in its promotional material about most of facilities provided by Islamic banks.

\section{Conclusions}

An Islamic bank that aim to be morally responsible in adopting Islamic marketing policies often faces difficulties in determining how popular their products should be. This difficulty is compounded by the fact that economic costs attach to making products safe. These costs must be reflected in the price of a product. Thus an Islamic bank that should develop its products much popular than its competitors will have to sell those products at a comparatively reasonably price and risk suffering a corresponding disadvantage in the marketplace. In this paper we discuss the sales behaviour relevant to Islamic banking that are concerned to follow the Islamic marketing ethics in socially responsible ways and to protect their place in a competitive market.

This research has several implications for practitioners. In our discussion it is emphasised that Islamic ethical behaviour will have a major impact on the development and maintenance of the buyer-seller relationship. Therefore, Islamic banks that value the critical importance of long-term relationships with their customers, should achieve an 
environment in which the potential for unethical behaviour is at a minimum. In doing so, the management should take follow up action on the following points:

(1) The need to create, communicate and enforce a thorough corporate code of Islamic ethics. Employees should know that management is taking serious action to ensure that the code is followed. When a violation arises, it is extremely important that employees are informed of punitive actions taken against the violator.

(2) The code of Islamic ethics must form the basis of ongoing training regarding the handling of ethical dilemmas. The management of the Islamic bank needs to design sales training programs where the sales manager can present salespeople or CRA with several different potential Islamic ethical scenarios and solicit how they would respond to each one. Customer Relation Advisors (CRA) can then discuss how the organization desires such situations to be handled.

(3) The managers of the Islamic bank should try to communicate with their customer relation advisors (CRAs), assisting and guiding them in accurately viewing their day-to-day sales activity from an Islamic ethical perspective; then they should not reward them on a $100 \%$ commission based on the sales made, but evaluate their various activities, not just the outcomes achieved (sales volume). This research does not imply that Islamic banks should avoid incentive programs, rather they could use a combination of base salary plus incentive pay in the form of commissions, bonuses or both based not only on the sales performance but on how well long-term objectives such as customer satisfaction have been achieved.

Given the key importance of customer trust in the Islamic banking and financial services sector, it is recommended that Islamic banks should emphasize frontline employees' Islamic ethical behaviours that particularly lead to customer trust. Put simply, they need to be honest and implement low-pressure selling techniques.

\section{References}

Ahmad, M. (1995) Business Ethics In Islam, IIIT, Islamabad.

Anas, M. (1989) Muwatta Imam Malik - The First Formulation of Islamic Law", Translated by Aisha Bewley, Kegan Paul International, London.

Beatty, S.E., Mayer, M., Coleman, J.E., Reynolds, K.E. and Lee, A. (1996) "Customer-Sales Associate Retail Relationships", Journal of Retailing, 72(3): 223-247. 
Chonko, L.B. and Burnett, J.J. (1983) "Measuring the Importance of Ethical Situations as a Source of Role Conflict: A Survey of Salespeople, Sales Managers, and Sales Support Personnel", Journal of Personal Selling and Sales Management, 3: 41-47.

Chonko, L.B. and Hunt, S.D. (1985) "Ethics and Marketing Management: An Empirical Investigation", Journal of Business Research, 13: 339-359.

Cooper, R.W. and Frank, G.L. (2002) "Ethical Challenges in the Two Main Segments of the Insurance Industry: Key Considerations in the Evolving Financial Services Marketplace”, Journal of Business Ethics, 36: 5-20.

Cronin, J.J. Jr. and Taylor, S.A. (1992) "Measuring Service Quality: A Re-examination and Extension", Journal of Marketing, 56, (July): 55-68.

Crosby, L.A. and Stephens, N. (1987) "Effects of Relationship Marketing on Satisfaction, Retention, and Prices in the Life Insurance Industry", Journal of Marketing Research, 24: 404-411.

Crosby, L.A., Evans, K.R. and Cowles, D. (1990) "Relationship Quality in Services Selling: An Interpersonal Influence Perspective", Journal of Marketing, 54: 68-81.

Dabholkar, P.A. (2000) "Technology in Service Delivery: Implications for Self service and Service Support", In: Swartz, T.A. and lacobucci, D. (Eds), Handbook of Services Marketing and Management, Sage, Thousand Oaks, CA, pp: 103-110.

Dubinsky, A.J., Jolson, M.A., Kotabe, M. and Lim, C.U. (1991) "A Cross National Investigation of Industrial Salespeople's Ethical Perceptions”, Journal of International Business Studies, 1(4): 651-670.

East, R. (1997) Consumer Behaviour: Advances and Applications in Marketing, Prentice Hall, London.

Enis, B.M. (1980) "Invited Essay JPSSM: New Forum for Research in Marketing's Most Pervasive Field", Journal of Personal Selling and Sales Management, 1(1): 6-10.

Erol, C. and el-Bdour, R. (1989) "Attitudes Behaviour and Patronage Factors of Bank Customers Towards Islamic Banks", International Journal of Bank Marketing, 7(6): 31-42. Focus Across the Firm." $2^{\text {nd }}$ Edition, McGraw-Hill.

Farrell, T.A., Hall, T.E. and White, D.D. (2001) "Wilderness Campers' Perception and Evaluation of Campsite Impacts", Journal of Leisure Research, 33(3): 229-250.

al-Faruqi, I.R. (1992) al-Tawhid: Its Implications for Thought and Life, IIIT, Kuala Lumpur.

Futrell, C.M. (2002) Fundamentals of Selling: Customers for Life, $7^{\text {th }}$ Edition, New York: McGraw-Hill.

Futrell, R., Shafer, D. and Shafer, L. (2002) "Quality Software Project Management", Prentice Hall, New Jersey.

Ganesan, S. (1994) "Determinants of Long-Term Orientation in Buyer-Seller Relationships", Journal of Marketing, 58(April): 1-19.

Ganesh, J., Arnold, M.J. and Reynolds, K.E. (2000) "Understanding the Customer Base of Service Providers: An Examination of the Differences between Switchers and Stayers", Journal of Marketing, 64, (July): 65-87.

Garbarino, E. and Johnson, M.S. (1999) "The Different Roles of Satisfaction, Trust, and Commitment in Customer Relationships", Journal of Marketing, 63 (April): 70-87.

Gerrard, P. and Cunningham, J.B. (1997) "Islamic Banking: A Study in Singapore", International Journal of Bank Marketing, 15(6): 204-216.

Gundlach, G.T. and Murphy, P.E. (1993) "Ethical and Legal Foundations of Relational Marketing Exchanges", Journal of Marketing, 57 (Oct.): 35-46.

Haron, S.N.A. and Planisek, S. (1994) "Bank Patronage Factors of Muslims and non- Muslim customers", International Journal of Bank Marketing, 12(1): 32-40.

Hegazy, I.A. (1995) “An Empirical Comparative Study Between Islamic and Commercial Banks' Selection Criteria in Egypt", International Journal of Contemporary Management, 5(3): 46-61. 
Howe, V., Hoffman, K.D. and Hardigree, D.W. (1994) "The Relationship between Ethical and Customer-Oriented Service Provider Behaviours", Journal of Business Ethics, 13(July): 497-506.

Ibn al-Ukhuwwah, Diya' al-Din Muhammad (1983) Ma'alim al-Qurbah fi Ahkam al-Hisbah, Translated by Reuben Levy, Luzak, London.

Ibn Taymiyah (1982) Public Duties in Islam: The Institution of the Hisbah, translated by Muhtar Holland, The Islamic Foundation, Leicestershire.

Jamal, A. and Kamal, N. (2003) "Factors Influencing Customer Satisfaction in the Retail Banking Sector in Pakistan”, International Journal of Consumer Marketing, 13(2): 20-52.

Kennedy, M.S., Ferrell, L.K. and Leclair, D.T. (2001) "Consumers' Trust of Salesperson and Manufacturer: An Empirical Study", Journal of Business Research, 51: 73-86.

Liljander, V. and Mattson, J. (2002) "Impact of Customer Pre-consumption Mood on the Evaluation of Employee Behaviour in Service Encounters", Psychology and Marketing, 19: $837-860$.

Metawa, S.A. and Al-Mossawi, M. (1998) "Banking Behaviour of Islamic Bank Customers: Perspectives and Implications", International Journal of Banking, 16(7): 299-313.

Miller, I.J. (1996) "Ethical \& Liability Issues Concerning Invisible Rationing", Professional Psychology: Research \& Practice, 27: 583-587.

al-Misri, A.N. (1991) The Reminiscences of the Traveler: A Classical Manual of Islamic Sacred Law, Trans. by Noah Ha Mim Keller, Abu Dhabi: Modern Printing Press.

Naser, K. and Moutinho, L. (1997) "Strategic Marketing Management: The Case of Islamic Banks", International Journal of Bank Management, 15(6): 187-203.

Naser, K., Jamal, A. and Al-Khatib, K. (1999) "Islamic Banking: A Study of Customer Satisfaction and Preferences in Jordan", International Journal of Bank Management, 17(3): 135-150.

al-Nawawi, Imam (nd) “Riyadhus-Saleheen,” Trans., S. M. M. Abasi, IIPH, Riyadh.

Niazi, L.A.K. (1996) "Islamic Law of Contract", Lahore: Research Cell, Dayal Sing Trust Library.

Nicholson, Carolyn Y., Compeau, L. D. and Sethi, R. (2001) "The Role of Interpersonal Liking in Building Trust in Long-Term Channel Relationships," Journal of the Academy of Marketing Science, 29(1): 3-15.

Oliver, R.L. and De Sarbo, W.S. (1988) "Response Determinants in Satisfaction Judgements", Journal of Consumer Research, 14: 495-507.

al-Qur'an -English translation and commentary (The Meaning of the Glorious Qur'an) rendered by Abdullah Yusuf Ali (1983), Maryland(USA): Amana Corporation.

al- Razi, M. (1985) Tafsir Fakhr al-Razi. $3^{\text {rd }}$ edition, Dar al-Fikr, Beirut.

Richens, M.L. (1983) "Negative Word of Mouth by Dissatisfied Consumers: A Pilot Study", Journal of Marketing, 46 (Winter): 69-74.

Saeed, M., Ahmad, Z.U. and Mukhtar, S.M. (2001) "International Marketing Ethics from an Islamic Perspectives: A Value Maximization Approach", Journal of Business Ethics, 32: 127-142; Salesperson Selling Behaviors on Customer Satisfaction with Products." Journal of Retailing, 73(2): 171-183.

Shaw, M. (1996) "Civil Society and Media in Global Crises", St. Martin Press, London.

Sheperd, C.D. (1999) "Service Quality and the Sales Force: A Tool for Competitive Advantage", Journal of Personal Selling and Sales Management, 19(3): 73-82.

Singh, J. (1991) "Understanding the Structure of Consumers' Satisfaction Evaluations of Service Delivery", Journal of the Academy of Marketing Science, 19 (Summer): 223-244.

Solomon, M.R., Surprenant, C., Czepiel, J.A. and Gutman, E.G. (1985) "A Role Theory Perspective on Dyadic Interactions: The Service Encounter", Journal of Marketing, 49 (Winter): 99-111. 
Strutton, D., Pelton, L.E. and Tanner Jr., J.F. (1996) "Shall We Gather in the Garden: The Effect of Ingratiatory Behaviours on Buyer Trust in Salespeople", Industrial Marketing Management, 25: 151-162.

Swan, J.E. and Nolan, J.J. (1985) "Gaining Customer Trust: A Conceptual Guide for the Salesperson." Journal of Personal Selling and Sales Management, 5(Nov.): 39-48.

Swan, J.E., Trawick Jr.I.F., Rink, D.R. and Roberts, J.J. (1988), "Measuring Dimensions of Purchaser Trust of Industrial Salespeople", Journal Personal Selling and Sales Management, 8 (May): 1-9.

Tansey, R., Brown, G., Hyman, M.R. and Dawson, Jr.L.E. (1994) "Personal Moral Philosophies and the Moral Judgements of Salespeople", Journal of Personal Selling and Sales Management, 14(Winter): 59-75.

Taylor, S. and Baker, T.L. (1994) "An Assessment of the Relationship between Service Quality and Customer Satisfaction in the Formation of Consumers' Purchase Intentions", Journal of Retailing, 70: 163-178.

Trawick, I.F., Swan, J.E., McGee, G.W. and Rink, D.R. (1991) "Influence of Buyer Ethics and Salesperson Behaviour on Intention to Choose A Supplier", Journal of the Academy of Marketing Science, 19(1): 17-23.

Tse, D.K. and Wilton, P.C. (1988) "Models of Consumer Satisfaction Formation: An Extension." Journal of Marketing Research, 25: 204-212.

Tyser, C.R., Demetriades, D.G. and Efendi, I.H. (1967) "A Complete Code on Islamic Civil Law," (Translation from Turkish of Majallah-el Ahkam-i-Adliya, Majella, Lahore), New York: Law Publishing Company, NY.

Whalen, J., Pitts, R.E. and Wong, J.K. (1991) 'Exploring the Structure of Ethical Attributions as a Component of the Consumer Decision Model: The Vicarious Versus Personal Perspective', Journal of Business Ethics, 10: 285-293.

Wotruba, T. (1990) "A Comprehensive Framework for the Analysis of Ethical Behaviour with a Focus on Sales Organisations", Journal of Personal Selling and Sales Management, 10(Spring): 29-42.

Wray, B., Palmer, A. and Bejou, D. (1994) "Using Neural Network Analysis to Evaluate BuyerSeller Relationships", European Journal of Marketing, 28(10): 32-48. 


\section{القيم الإسلامية للتسويق و أثز ها في كسب رضا العميل في صناعة الصبرفة الإسلامية}

أبو الحسن، وعبدالقادر شاشي**، وسلمى عبداللطيف**

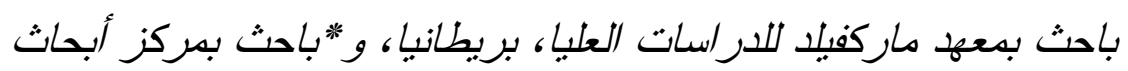

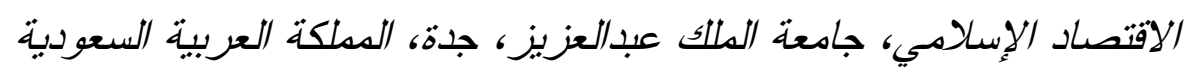
و **مديرة مركز الصيرفة الإسلامية والتدويل والإدارة جامعة بروناي، دار السلام، بروناي

السستخلص. تجمع القيم الإسلامية للتسويق بين مبدأ تعظيم القيمــة

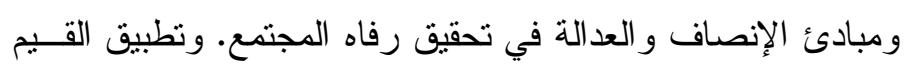

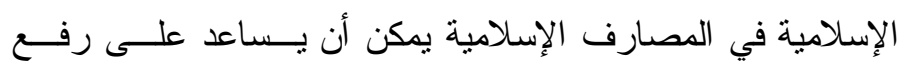

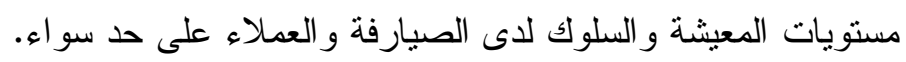

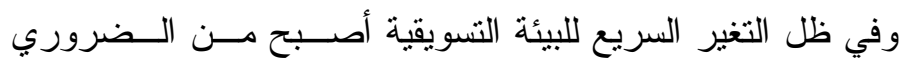
التركيز على العملاء لكسب رضاهم بقدر لم يسبق له مثيل من قبل.

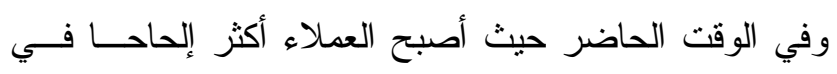
طلباتهم، و أكثر تتقلا بين المتافسين من مقدمي الخدمات المالية، لم الم

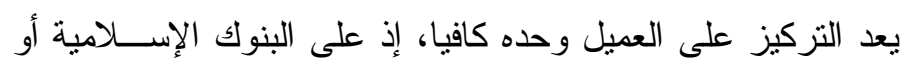

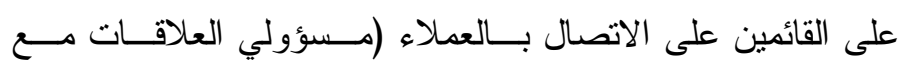

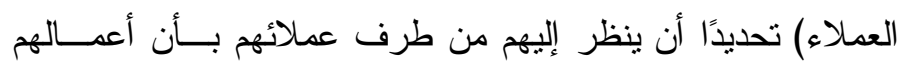
متو افقة مع الشريعة الإسلامية. تمنتل هذه الدر اسة خطوة أولية في تحليل دور القــيم الإســامية

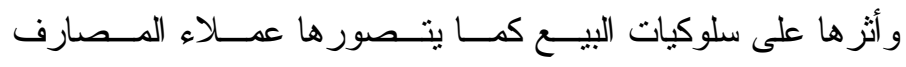

